\title{
Ethnicity, Socialization and the Security of Lives and Propertyin Nasarawa State
}

\author{
Sarkinfada Mohammed Abdul \\ Faculty Of Education A.B.U. Zaria. School Of Arts And Social Science Education Social Studies Section
}

\begin{abstract}
Ethnic ties have such a strong hold in Nigeria and indeed Nasasrawa state. Considering the unending schism, chauvinism and antagonism among ethnic groups in Nasarawa State, The best practice on how best to manage this unfortunate scenario remains topical. This paper among other factors examines ethnicity in Nasarawa State,the paper traces how ethnic identity socialization is manipulated to trigger interethnic relation leading to destruction of lives and property. Politics of ethnicity, economic and psychological factors were discussed as constants influencing ethnic conflict. Recommendations were made on how best to address the challenges of ethnic conflicts in Nasarawa State.
\end{abstract}

Key words; Ethnicity, socialization, security of lives and properties, Nasarawa state.

\section{Introduction}

Nigeria is made-up of diver's ethnic groups. The three largest ethnic groups are Igbo, Yoruba and Hausa/Fulani. Representing 71\% of Nigerian population “ (Otite, 1990). Other less populous ethnic groups were subsumed in the big ones. Otite (1990) listed 374 ethnic in the 1980s. Onwuejeogwu (2007) listed over 480 ethnic groups in Nigeria. Nasarawa state is a multi ethnic state; Onwuejeogwu (2007) put the figure of ethnic groups in Nasarawa state at 10. Hassan and Wakawa (2012), observed that ethnically, Nasarawa state is extremely divers, the tribes found include: Hausa, Kanuri, Fulani, Alago, Mada, koro, Rindre, Gandara, Gade, Gbaggi, Mama, Toni, Yeskwa, Bassa, Kwatto, Afo, Kwara." It is worthy to note that, there are other tribes found in Nasarawa state who are also indigenes of the state.

Nasarawa state is a collection of tribes; however, what characterize relationships between tribes are mutual suspicion, hate and fear. Tribalism is the lowest level of human development and civilization, it is the stage where human beings were seen as barbaric invaders of civilization; socialization is restricted to intra group or within group. Several parts of Nigeria and indeed Nasarawa state are today facing the challenge of intra and inter-ethnic conflicts leading to destruction of lives and property. The political elites in their quest to acquire political power or other advantages manipulate ethnicity to achieve their goals. "Ethnicity remains a factor in Nigerian politics the elites see ethnicity as a fall back mechanism in settling scores where there is disagreement amongst them," (Attoh, Soyombo, 2011). There is the threat of anarchy in some parts of Nasarawa State, in an effort to combat these threats the state government expended huge financial resource, McBride, Milante and Skaperdas (2011) argued that "once conflict begins whatever capital of conflict management that existed before hand can quickly depreciate". The socialization of Nigerians' by the colonialist has played a significant role on the attitude of Nigerians. The internalization of different form of discrimination in Nigeria found its root during the colonial era. In Nigeria, language is a strong factor that determines how people relate, people who share common language tend to relate closely. This study seeks to achieve the following objectives.

1 , to examine ethnicity in Nigeria with reference to Nasarawa state

2 , to analyze how ethnic identity socialization influences the destruction of lives and property in Nasarawa state 3 to analyze politics of ethnicity, economic and psychological factors that influence ethnic conflicts

Conceptual and theoretical analysis of ethnicity and socialization on the security of lives and properties in Nasarawa state

The concept of ethnicity: The definition of ethnicity has been provided by various scholars. Ottite (1990)Defined ethnicity as the "consciousness of belonging and being loyal to a social group distinguished by shared cultural traditions, a common language in-group sentiment and identity' Nnoli (1980), viewed ethnicity as a social phenomenon associated with interaction among members of different ethnic group". But for the purpose of this article, we are going to adopt the definition of ethnicity by Osaghae (1995), "ethnicity is the mobilization of ethnic identity and difference to gain advantage in situation of Competition, conflict or 
cooperation. "This definition indicates that ethnicity is neither natural nor accidental, but conscious effort by social actors.

The concept of socialization: According to Wentworth (1980) socialization must leave room for free human autonomy, though noting the patterned social structure and processes that influence individual". Persell (1990), conceptualized socialization as preparing new comers to become members of an existing group and to think, feel and act in a manner the group consider appropriate".Persell further distinguishes three major aspect of socialization namely, (a) the context in which it occurs (b) the actual content and processes people use to socialize others (c) the results arising from those context and processes. These three major aspects of socialization is very useful for the current article because it provides a good frame for analyzing socialization within the context of ethnicity.

Nasarawa state like other state in Nigeria has often been compelled to deal with the issue of ethnic integration especially in moment of extreme ethnic disagreement which has sometimes degenerated into violent conflicts with the attendant destruction of human lives and property. "Before colonial rule, ethnic groups in Nigeria had remained largely separated although some form of interaction inform of trade, religious ties and sometimes politics did occur" (Ikimi , 2006). Ethnic groups in Nasarawa state may have natural existence; the consciousness about making them active and functional is a deliberate effort by social actors and the political elite through political engineering. "As a phenomenon, ethnicity is behavioral in form and conflictual in content, people from different ethnic group see each other as competitors in the quest for resource rather than compatriots" (Attoh, 2011). The relationship between divers ethnic group in terms of competing for scares resource within the political state is what gave rise to ethnicity. In Nasarawa state, the conflictual nature of ethnicity is caused by inter-ethnic competition for scares resources, this is associated with inter-ethnic discrimination in terms of available jobs, political appointment, scholarships and admission into tertiary institutions among others, as a result, merit is sacrificed on the altar of ethnicity.

\section{Socialization processes in Nasarawa state.}

Socialization processes is dynamic in nature, it changes when the need, value and aspiration of the society changes. Needs, value and aspiration can be individual or collectively for members of the society. Socialization entails preparing new comers to become members of an existing group and to think, feel and act in ways the group considers appropriate (Persell, 1990), however, it is worthy to note that sometimes individual needs do conflict with social expectations of a group. For Example, students cheat in an examination but they know they are not supposed to cheat, but they do so anyway.

For the purpose of this article, our analysis would be based on Persell (1990), three major aspect of socialization, namely ; ( a) the context in which it occurs, ( b)the actual content and (c)processes people use to socialize others.

Context: ethnic socialization; this describes how members of society or community are socialized to become active members and identify themselves to a particular ethnic group. "Ethnic group tend to be the one in which the individual claims heritage" (Phinney, 1996). Ethnic identity is not the same as individual personal identity, the later is concerned with individual personal identity attribute in the socialization processes while the former deals with individuals ethnic awareness, ethnic attitude, ethnic self identification and ethnic behavior. Ethnicity patterns our ways of behavior. The diver's ethnic groups in Nasarawa state have individual socializing structure for its members; this explains why ethnic groups in Nasarawa state behave differently in terms of cooperation tend to influence each other. Wentworth (1990) argued that " an adequate view of socialization most leave room for free will and human autonomy, though acknowledging the patterned social structure and process that influence individuals". New members may learn the behavior and attitude that old members anticipate they would learn. The content of socialization may include ideology, method of identifying with strangers of other ethnic groups, strategies and socializing activities. Persell (1990) opined that "the content and process of socialization is like play, the line and the actors.

The process of socialization; The process of socialization are the interactions that are conveyed to new members, how they speak, behave, think and even feel in their day to day interaction with members of the society.

The failure of the state to establish the rule of law and practice its tenets and failure of the justice System to address serious national issues such as corruption, injustice, and unemployment and election dispute has compelled many Nigerians to take laws into their hands. Ayetti (2012), postulate that "the absence of a constitution breeds lawlessness, government dysfunctions and retards economic development, the moral value system collapse in a constitutional vacuum". Lawlessness in Nigeria has laid the foundation for anarchy to 
reign. "Weak political system is more prone to conflicts than established political system and stronger bureaucracies" (fearon,2010).

Because of the needs, values and aspiration of various ethnic groups in Nasarawa state to acquire political power and other advantages, they use all means necessary to undo each other. The political elites in Nasarawa state manipulate ethic difference in their bid to gain access to political office, this often leads to violent conflict that claim lives and property. The political elite employ the services of aresource person or socializer within their ethnic group, members are mobilized to participate in meetings, indoctrination is used as a means of transmitting ideology, beliefs, attitude, ethnic self identification and how members will speak in unionism in terms of cooperation, conflicts and competition, even when the socializer is aware that indoctrination is morally wrong. "An indoctrinated person lives self-deception, the grounds for his/her belief is beyond rational reason and one holds his/her conviction despite of counter evidence" (Willson in Snook,1972). The ethnic socialization of novices by old members is sustained through political socialization, as a concept, political socialization is "the way society transmits its political culture from generation to generation"(Anifowose,Enemuo,1999). This could explain why ethnicity is still in existence despite efforts to curtail it. With the development in information communication technology (ITC) ethnicity has intensified, people communicate easily through the use of cell phone, face book and other social networks. It is worthy to note that members of the same ethnic group who are socialized within the narrow confine of ethnic socialization behave the same in terms of identifying with their group. For Example a professor in London of Nigerian origin and a local man in a Nigerian village who has not attended primary school share the same opinion when it comes to identifying with their ethnic group.

\section{Effect of ethnic conflicts on the security of lives and property in Nasarawa State}

Ethnic-based conflict in Nasarawa state has claimed many lives and the destroyed many Property, below are some of the reported conflict. "Over 25 killed, scores wounded, houses burnt in Agyragu community by Eggon youths" (Ireporters.com Nov,21,2012). "No fewer than 17 persons in Agatu community including women and children were killed by gun men suspected to be Tiv at Rukubi in Doma local government area of Nasarawa state more corpses are being recovered from the surrounding bushes." (Nigerian pilot, june, 04,2013)." " ${ }^{\text {th }}$ of May ten members of state security service and policemen were killed in the most gruesome manner by the Ombaste spiritual group in Alakyo village in Lafia local government area of Nasarawa state. "(Nigerian pilot, June .04.2013). " the killing is too much, more than 13 towns and villages have been destroyed in the past two months. The killing of Cows and other live stock cannot produce peace." (Maku, Feb., $10^{\text {th }}$, 2013). "Traditional ruler burnt alive alongside his sister and nine others in Agyragu by Ombaste, a spiritual group of Eggon people of Nasarawa state, houses burnt properties destroyed."(Information Nigeria, Nov, 11, 2012).

Literally, Nasarawa state has become a killing field where all sorts of killings are taking place even without provocation, several ethnic groups have pick-up arms against each other in a bid to further pursue their narrow nationalistic attitudes, this unfortunate development is cause for concern for any patriotic citizen of Nasarawa state and Nigeria at large. Successive government in Nasarawa state have taken measures aimed at addressing the challenges of ethnic conflicts but ethnic killings has continued unabated. The current governor of Nasarawa state Tanko Almakura has taken proactive steps to ensure peace and stability in the state, but the more the effort the more challenge of ethnic killings in the state. Where do go from here.

\section{Factors Influencing Ethnic Conflict In Nasarawa State}

There are several factors influencing ethnic conflicts in Nasarawa state, for the purpose of our analysis we are going to examine three, namely; politics of ethnicity, Economic and psychological factors.

1, Politics of ethnicity: politics of ethnicity is a principal factor responsible for some ethnic conflicts in Nasarawa state, politics is a game of numerical strength if carefully coordinated to make it influence the outcome of an election, the former governor of Nasarawa state Alhaji Abdullahi Adamu 1999-2007 argued that "politics is a game of number but it is also more importantly the game of financial muscles" (Adamu,2002). Adamu further stated that "the majority tribes are not necessarily the king or king makers because they the lack financial muscle to exercise the kind of influence they should, giving their numerical superiority" in a situation where numerical strength is marginalized by money, there is bound to be a problem or conflict. The issue of majority and minority ethnic group is now renting the air in Nasarawa state, even though such claims only exists in nomenclature. We can put the issue of majority and minority to test by this illustration; we have 26 ethnic groups in Nasarawa state, suppose we have an ethnic conference where each ethnic group is to present one representative, a total of 26 representatives will suffice. The question is this, is it possible for one or two ethnic group out of 26 to claim majority or superiority? This is how majority becomes ineffective when it comes to the outcome of an election. This is how reality works, but because of blind pursuit of tribal ambition some people assumed it is a right for one of their own to win an elective position, in event of losing an election, retroactive 
resentment sets-in which sometimes lead to violent conflicts that claim lives and property. In a multi ethnic state like Nasarawa the way to win an election is by building political bridges across ethnic groups in the state.

2, Economic factor: The generally held belief by theories revealed that competition for scares resource is a common factor in almost all conflicts. In Nasarawa state various ethnic groups compete for jobs, land, and admission into tertiary institution, rights, political office and property. This competition often leads to conflicts 3, Psychological factor: psychological factor play a vital role in strengthening the ties of ethnicity in Nasarawa state. "Whenever one ethnic group is deprived of any opportunity or sidelined by any policy formulated by the government, it leads to the generation of feeling of relative deprivation, which leads to frustration and finally exhibited in form of conflict"(Kaur 2012). The redeployment policy in local government administration in 1999 by the administration of former governor of Nasarawa state Alhaji Abdullahi Adamu did not go down well with the Eggon ethnic group, there were feelings of frustration among them, the policy was perceived by the Eggon people as a way of victimizing them even though no one lost his job a result of the redeployment policy. "Frustration emerges when people start comparing themselves with those experiencing upward social mobility, the deprived start feeling that they too should experience the good life enjoyed by those experiencing upward social mobility, this create grounds for the occurrences of aggression, attacks and strengthening the feelings of ethnicity". (Gurr,1970 ). When one ethnic group is recognized and given more prominence than the others, it generates the feeling of relative deprivation; this can result to attacks on the ethnic group that is given more prominence

\section{Conclusion /recommendation}

The challenge of ethnicity is common phenomena in a multi-ethnic society such as Nasarawa state. Lately, ethnicity has generated tension and conflict in inter-group relation in Nasarawa state. Ethnicity can manifest in form of cooperation, disagreement and conflict, with the worst manifestations being that of disagreement leading to ethnic cleansing. Ethnic socialization which is different from individual personality development patterns' the way members of an ethnic group behave when it comes to identifying with their ethnic group. It is worthy of note that ethnicity and ethnic identity socialization are not destructive, the manipulation of ethnicity by the political elites makes it a factor that undermines national reconciliation and development. In the light of the assertions made, we recommend the following.

a, The ruling elites in Nigeria and indeed Nasarawa state should marshal out a plan that will encourage national discourse to enable various ethnic group air their views on what their challenges are.

B, for any meaningful development to take place in Nasarawa state, all ethnic groups must see themselves as belonging to one big family.

C, Justice, equity, fairness and respect for the rule of law should form the basis for government decisions.

D, Negativity in ethnic socialization should be strongly discouraged by various ethnic groups in Nasrawa state.

E, Those who killed innocent lives should be brought to justice to face the full wrath of law. This will serve as deterrence to others with motives of taking human lives.

F, traditional rulers and other stake holders should take proactive steps in discouraging ethnic militia in their respective community

\section{Refrenceses.}

[1]. Adamu, A. (2002). Ethnic conflict in Nigeria, speech by the former executive governor of Nasarawa State.

[2]. Attoh , F.\& Soyombo, O.( 2011). The politics of ethnic balancing in Nigeria, International journal of Sociology and Anthropology. vol .3 (2) pp 40-44, Feb, 2011.

[3]. Anifowose, R. \& Enemuo, C.R. (1999). Elements of politics, surulere,sam iroanusi publication.

[4]. Ayittey, G. (2012). The constitutional vacuum. Retrieved from Saharareporters . com. 01.06.2013.

[5]. Fearon, J. (2010). Do governance predict anything? The case of fragile states and civil war. Background Paper prepared for world development report 2011 on conflict, security and development.

[6]. Gurr, T.R. (1970). Why Men rebel, Princeton, Princeton university press.

[7]. Hassan, S. \& Wakawa, A. (2012), Muslim of Nasarawa state: a survey. Nigerian research network.

[8]. Ikimi, O. (2006). History, the Historian and the Nation, Ibadan, Heinemann educational books Nigeria Plc.

[9]. Information Nigeria (2012), traditional ruler burnt alive. www.information.com/2012/11/narawa... Ireporters (2012) over 25 killed. Ireportersng .com/2012/11/21/over-25.

[10]. Kaur, s. (2012). Understanding ethnicity in Nigeria, international journal of social science tomorrow, vol .1 No.7. 2012.

[11]. McBride, M. \& Milante,G. \& Skaperdas, S. (2011). Peace and war with endogenous state capacity. Journal of conflict resolution, Vol 55. No3 june 2011.

[12]. Nigerian pilot (june, 04,2013), harvest of ethnic killings in Nasarawa state. www.nigerianpilot.com/harvest-of-et....

[13]. Nnoli, O. (1980). Ethnic politics in Nigeria, Enugu, fourth dimension publishers.

[14]. Onwuejegwu, M.A (2007). The national multi ethnic nationalities of Nigeria and the problem of Governance. Lecture series, national institute for cultural orientation (NICO) Abuja.

[15]. Osagae, E. (1995). Structural adjustment and ethnicity in Nigeria, Uppsala Nordic African Institute.

[16]. Otite, O. (1990). Ethnic pluralism and ethnicity in Nigeria, Ibadan, shaneson c.i. ltd

[17]. Persell.C.H. (1990), understanding society, 3rd ed. New York, Harper and row publishers inc.

[18]. Snook, T. (1970). Indoctrination and education RKP London.

[19]. Wentworth, W.M.(1980). Context and understanding: an inquiry into socialization theory, New York, Elsevier. 